which it is compatible; the hairpin configuration is still discussed and illustrated.

There are liberal quotations from many research workers, which may, as the author hopes, illustrate their contribution and philosophy; unfortunately they often punctuate the narrative flow and sometimes illustrate a turgid style. Students may like to read these extracts and it is certainly helpful to mention the authors of various experiments, although I am puzzled by the subtle gradations which have decreed that some have Christian names, others initials and a few neither.

This book does not supersede other similar paperbacks in this well-publicized field, despite several useful features. P. M. B. WALKER

\section{BIOLOGICAL PROBLEMS}

Problems in Quantitative Biology

(Biological Science Texts.) By J. F. Eggleston. Pp. ix +226 . (London: The English Universities Press, Ltd., 1968.) 22s. $6 d$.

THIS collection of numerical examples is intended to promote the teaching of biology as an exact science by providing exercises which give sixth form and first year university students experience in handling quantitative biological information, and help them to apply mathematical skills and assess the error and degree of significance involved. It might in some ways be regarded as an English counterpart of Joseph Schwab's Invitations to Enquiry.

The book is organized in two sections. The first part comprises eight groups of analytical and numerical problems concerning physiological processes in plants and animals. These groups deal severally with respiration and gaseous exchange; photosynthesis; water relations of animals and plants; ion uptake and loss in animals and plants; muscle and skeletal physiology; kidney and excretion; and statistics and genetics. The second part, printed on distinguishing green paper and coded to correlate easily with the first part, claims to give a detailed consideration of the problems posed in the first part, together with their solutions. To a professional mathematician the explanations might appear somewhat imprecise and inadequate.

It is a truism that the quality of learning is determined by the quality of the teacher; certainly the educational use of this book calls for knowledge, skill and discrimination of a high order on the teacher's part. It would be his task to select the problems appropriate to his pupils' sophistication both in biological concepts, facts and principles and in mathematical expertise, unless the text were to provide merely a collection of arid exercises. Such a concentration of examples might well daunt those who take a more broadly humanistic view of the biological sciences than is at present fashionable, though the insufficiently numerate biology teacher might well find some reassurance in the second part of the book.

There is certainly wide variety in the problems posed and this gives a helpful idea of the many aspects of biology which lend themselves to numerical treatment; nevertheless, mathematical problems should come into biology only if they elucidate a particular aspect of the subject. Too often these problems seem artificial, thought up to involve some mathematical skill or physico-chemical consideration.

Far from "spreading alarm and despondency" as the author fears, the introduction of material from original papers and advanced texts is a welcome and redeoming feature of the book. It is certainly in accord with the current dernand for relevance at all educational levels. Unfortunately, the text lacks documentation and, if the author's hope that pupils will be stimulated to refer to reference books is to be fulfilled, an adequate bibliography is essential.
Mathematics in the forms suggested by this book can indeed be a most useful precision tool for occasional use by a knowledgeable and discriminating practitioner, but as a "weapon in his armoury" the average teacher might well find such a concentrated device as this rather dangerously two-edged.

Problems in Quantitative Biology should be regarded with caution as a teacher's reference book rather than adopted unreservedly as a student's text.

\section{E. J. VINNICOMBF:}

\section{GENETICS REVIEWED}

\section{Annual Review of Genetics}

Vol. 1. Edited by Herschel L. Roman in association with Laurence M. Sandler and Gunther S. Stent. Pp. 334. (Palo Alto, California: Annual Reviews, Inc., 1967.) n.p.

THIs volume inaugurates a new member of the Annual Reviews series. The usual two questions arise: is it required, and if so, is it good? For once the answers can both be in the affirmative. Though most first issues manage to be good, this is exceptionally so. The quality and composition of the editorial committee-Crow, Luria, Owen, Rhoades, Roman and Tatum-promise that the standard will continue. H. L. Roman's editorship, in association with L. M. Sandler and G. S. Stent, is further guarantee.

Genetics has at last permeated the whole of biology. Often unaware, now every biologist "does" some genetics. The result is that those more primarily interested in the genetic aspects of any one problem are faced with the difficulty of scattered literature. An Annual Review of Genetics is required to make this task easicr.

The first issue covers both highly specialized and more general topics. Picking and choosing: the chapters on "Human Genetics" by H. E. Sutton and "Population Genetics" by R. C. Lewontin stress the generality of balanced polymorphism from man to Drosophila. A masterly article by C. Yanofsky reviews the five principal sources of evidence - two from bacteriophage and three from Escherichia coli-which have demonstrated the co-linearity between the nucleotide sequence of a gene and the amino-acid sequence of the polypeptide chain encoded in that gene. S. Emerson, in "Fungal Genetics", stresses the unique contribution of tetrad analysis to the investigation of the mechanisms of recombination. As to "Developmental Genctics", H. Ursprung stresses the change from the analysis of developmental pathways disrupted in mutants to that of sequential activity of genes in terms of messenger production.

Those mentioned are only five of the thirteen review articles of this volume, all of which are valuable.

\section{G. Ponteconvo}

\section{TAXONOMY OF PLANTS}

\section{Plant Variation and Classification}

By Ritchie C. Bell. (Fundamentals of Botany Series.) Pp. vi +135. (London: Macmillan and Co., Ltd., 1967.) $12 s .6 d$.

THIs is a typical "curate's egg" book; the sections on variation are very well donc, while those on classification are weak in a number of places. It suffers all the way through, also, by leaning too heavily on theoretical examples where a little searching through the literature would have revcaled actual ones of much greater interest and value to the student.

After an introductory chapter on variation and classification the author goes on to discuss nomenclature and keys; this chapter is reasonably well done, but at least 